\title{
On Frost's Colorful Imagery with Profound Implication
}

\author{
Qian Chen \\ Dept. of Foreign Language, Dezhou University, Dezhou, China \\ Email: cqbhh@126.com
}

\begin{abstract}
Robert Frost prefers employing common imagery to help express profound ideas. This leads to the deceptive simpleness of his poetry. The understanding of the imagery is crucial to the understanding of his poetry. Through the analysis of the colorful and ordinary imagery world, the poet's deep thoughts on nature and society is manifested: he finds nature both benevolent and violent; and facing the chaotic and disordered reality, poetry composition can provide a momentary escape for him and enable him to be courageous enough to treat the reality.
\end{abstract}

Index Terms - colorful imagery, profound implication, metaphor

\section{INTRODUCTION}

Image appears frequently in Frost's poems. In 1923, in answer to a question about his philosophy, Frost began by recalling that he had been baptized and brought up a Swedenborgian. He found persuasive Swedenborg's theory of a correspondence between natural facts and the world of spirit. It is in Emerson's Nature of 1836 that Frost finds the most compelling argument yet written by an American that natural facts are symbols of spiritual facts. Exploiting that conviction in poetry, Frost takes as his symbolic examples many of the same ingredients of the New England scene-farms, snowstorms, winds, birds, rivers - that Emerson has developed for his own purpose.

Walden (by Henry David Thoreau) influenced Frost a lot. In Frost's poems, there are particular images and events that echo Walden, including walking back in time, getting lost, and reaching a spring at least in imagination. Most important is the similarity to passages in Walden of Frost's insisting on metaphor as the key to the "a momentary stay against confusion".

He once declared:"Metaphor, parable, allegory, synecdoche - all the same thing" (Marcus, 1991, p.14) . By "metaphor" he means all kinds of figures of speech, including imagery. Despite his insistence on the importance of diction, phrasing and intonation, Frost believes that metaphor is the essence of poetry, first because poets naturally think metaphorically, and second because they tend to convey their thoughts to others indirectly, by the suggestive power of metaphor.

In his The Figure a Poem Makes, he says:

The line will have the more charm for not being mechanically straight. We enjoy the straight crookedness of a good walking stick. Modern instruments of precision are being used to make things crooked as if by eye and hand in the old days (Frost, 1995).

"All thinking, except mathematical thinking, is metaphorical" (Potter, 1982, p.164), writes Frost in Education by Poetry. Men naturally think in terms of resemblances, some trivial and some significant. The correspondences between ideas and between objects, as Emerson has taught, are what began the process of poetic creation for Frost. All men perceive their world, and some become enthusiastic about the beauty or the strangeness of it. To tame this enthusiasm, the emotional response to experience, by filtering it through the intellect into metaphor is to subject it to artistic control. A poet must exercise his creative imagination to perceive and reveal to others correspondences with other phenomena which they may have noticed before but never thought of expressing. A reliance on suggestion, on the power of metaphor and symbolism, is natural to poets if not to all men as Frost sees it. It is certainly very like him to wish to remain reticent, to hide, as it were, behind his figurative language. He himself indicates this in "Revelation":

We make ourselves a place apart

Behind light words that tease and flout,

But oh, the agitated heart

Till someone really find us out . (Frost, 1995)

\section{THE COLORFUl IMAGERY WORLD}

Frost means all kinds of figures of speech by metaphor. The concrete images emerge as a strong base on which to build his metaphor. Plants is the most frequently occurred image. The orchis is Frost's favorite flower. It is the incarnation of beauty and holiness. The readers can see frequently in his poems this beautiful, attractive figure, such as in "A Late Walk" of $A$ Boy's Will:

I end not far from my going forth

By picking the faded blue

Of the last remaining aster flower 
To carry again to you (Frost, 1995)

The speaker's giving her a flower joins them in awareness of the season's sadness and affirms their bond, overcoming the sense of desolation. His carrying the flower to her "again" makes the personal gesture a lasting ritual between them.

The animal images presented in Frost's poems are also very rich. The animals in his poems seem to be interested in man, such as the butterfly that leads the speaker to the flowers in "The Tuft of Flowers":

But as I said it, swift there passes me by

On noiseless wing a bewildered butterfly,

Seeking with memories grown dim o'er night

Some resting flower of yesterday's delight. (Frost, 1995)

The swift action of the butterfly parallels the speaker's own yearnings; but the butterfly's disappointment in not finding a flower standing where it recently rested reinforces its desolation as well as his own.

The celestial world in Frost's poems is multi-colored and thought-provoking. In general, the celestial bodies represent beautiful things. Let's see the moon in "Moon Compass":

And a masked moon had spread down compass rays

To a cone mountain in the midnight haze (Frost, 1995)

The moon's measuring and contemplative embrace of a mountain is a parallel to a tender human embrace.

Frost's imagery of nature gives the readers a colorful picture. On the other hand, we can't ignore the imagery of familiar objects. They are arranged in such a way by Frost that they give the readers so deep an impression and enlightenment.

Readers might first think of "wall" while "Mending Wall" is mentioned. The wall always symbolizes limitation or barrier. In "Two Look at Two" a similar wall appears before the two lovers:

When they were halted by a tumbled wall

With barbed-wire binding. They stood facing this, (Frost, 1995)

The wall stands for barriers between the real and ideal and between humans and nature.

The images in Frost's poems are common objects and readers are familiar with them. They help make the poems appear to be simple and easy. The readers are apt to be misled by their superficial simplicity while reading the poems. Nevertheless, behind the rich world of Frost's images, conceals an unfathomable complexity. In order to study Frost's thoughts, we should enter deeply into his world of imagery.

\section{SUGGESTIONS AND IMPLICATIONS OF FROST’S IMAGERY}

\section{A. Expressing His Thoughts on Nature}

\section{A beautiful and benevolent nature}

Frost writes often about external nature - the mountains, lakes, woods, and fields, and the animals and plants found there. He appreciates nature and feels it is important. This point is expressed in many of his poem through images. From Frost's biography we know that he was a farmer-poet throughout his life; though in the latter half of his life, he did less farm work and more writing and lecturing. The original form of the table of contents for A Boy's Will includes a gloss for each of the poem. The gloss for "mowing" says"he takes up life simply with the small tasks" (Lathem, 1979, p.529). It is obvious that Frost likes this kind of life-farming while writing and lecturing. Through the description of mowing in field, the speaker tells us farm work is the only spiritual comfort. This experience is presented in past tense, but the scene seems to live in the speaker's mind as he remembers its quiet intensity in terms of overheard conversation between his scythe and its task-a conversation really his own. The scythe's whispering voice dominates the scene. He feels the sun's heat on his body and jokes that perhaps the scythe whispered in awe at the silence.

It was no dream of the gift of idle hours,

Or easy gold at the hand of fay or elf:

Anything more than the truth would have seemed too weak

...

The fact is the sweetest dream that labor knows.

My long scythe whispered and left the hay to make. (Frost, 1995)

With "It was no dream", the tone modulates into deep seriousness as he senses that anything expressed by such labor cannot be about easy achievements or mythical fancies. The next-to-last line, set off as a whole sentence, is one of Frost's knotty didactic statements. Fact stands in opposition to dream in the contrast between fancied rewards and real ones already mentioned, but fact as "sweetest dream" paradoxically gives fact the rich satisfactions of dream that hover over the whole entranced scene. Thus "fact"seems to be the act of labor itself, the specific harvest, and the reality confirmed by scene, labor and harvest.

In "A Passing Glimpse", the flowers briefly seen along a railroad track serve as the central symbol. The passing glimpse of the flowers is into a world of spiritual beauty, which can be seen only dimly in earthly things. The identity of the flowers can never quite be grasped. Had the speaker known just what he had seen, the vision might have been completed, though the flowers he names suggest this vision through their special qualities.

I name all the flowers I am sure they weren't:

Not Fireweed loving where woods have burnt- 
Not bluebells gracing a tunnel mouth-

Not lupine living on sand and drouth.

Was something brushed across my mind

That no one on earth will ever find? (Frost, 1995)

Fireweed springs from destruction, bluebells grow where a tunnel plunges into obscurity, and the lupine flourishes where nourishment and water are scarce, all showing the miraculousness of spiritual creation. Here, the flowers are a token of spiritual beauty.

In "Moon Compasses", the speaker steps out into a rain-drenched evening and sees the moon spread rays, toward the mountain below. He connects this scene with a tender human embrace. The moon's power of measuring and the mountain's exaltation connect the bestowal of worshipful status a female figure by a dominating male one. Frost's use of four dots instead of a period at the end of the poem shows the poet's reticence to complete his thoughts. But it is certain that Frost's speaker relates the beautiful natural scene to the sweetest feeling in human life. Nature, in Frost's mind, occupies an important position.

"In the Home Stretch" is a narrative with a minimal plot. A couple is in the home stretch of moving their household from a city dwelling to a farm. They are also in the home stretch of their whole lives - a desired goal. After moving into the house, the women looks through the window and sees the moon:

It is by that? Or by the moon? The new moon!

What shoulder did I see her over? Neither.

A wire she is of silver, as new as we

To everything. Her light won't last us long.

It's something, though, to know we're going to have her

Night after night and stronger every night

To see us through our first two weeks. (Frost, 1995)

The new moon represents a fresh start for them. Though their future is unpredictable, the women's determined love for the place as well as her faith in life suggests continued vitality.

2. A cruel and violent nature

Frost loves nature and turns to nature from human society. But he has a less optimistic view of nature. He conceives of the universe as a dichotomy between good and evil, and is much more conscious of the violence and evil at least potential in nature.

In "Once by the Pacific", the stormy Pacific is a massive symbol of dangers to civilization - the end of the world, with the same God who began the creation by saying: "Let There Be Light" now sending down the "opposite and imperative" (Warren \& Lewis, 1973, p.1871). The speaker, watching as if from a great distance, laconically issues a warning to humanity about terrible threats that seem more their concern than his.

The clouds were low and hairy in the skies,

Like locks blown forward in the gleam of eyes.

You could not tell, and yet it looked as if

The shore was lucky in being backed by cliff,

The cliff in being backed by continent;

It looked as if a night of dark intent

Was coming, and not only a night, an age.

Someone had better be prepared for rage.

There would be more than ocean-water broken

Before God's last Put Out the Light was spoken. (Frost, 1995)

The image of clouds "like locks blown forward in the gleam of eyes" reflects the aggression in the waves' stares. The sardonic understatement of the "something" the waves thought of doing implies unspeakably awful acts. Yet the speaker draws back as he says "You could not tell," pretending uncertainty about his apprehension but possibly vindictive in his thoughts about punishments deserved by humanity. Some mock casualness continues with another"it looked as if," this one broadening the threat from "a night"to"an age"and thus changing the merely geographical to the historical一that is, to the coming of another dark age.

Nature serves explicitly as a symbol for evil forces in the poem"Lodged".

They so smote the garden bed

That the flowers actually knelt,

And lay lodged-though not dead. (Frost, 1995)

The speaker sees rain and wind as personified conspirators against the garden flowers. "Smote" suggests murderousness, and "the flowers actually knelt" suggests the speaker's and the flowers' surprise at an assault from usually kind forces. They "knelt/And lay lodged" to protect themselves from what seemed to be injustice, like innocents nursing their wounds.

The snow-white swamps add more terror and depression to the situation in "The Rabbit-Hunter."Destruction remains a central theme in this poem. The speaker seems painfully both outside and inside the situation, empathizing with the hated hunter as well as the miserable rabbit.

Careless and still 


\section{The hunter lurks}

With gun depressed,

Facing alone

\section{The older swamps}

Ghastly snow-white. (Frost, 1995)

The "gun depressed" describes both the slant of the hunter's gun and speaker's mood. The snow-white swamps, with the hunter's existence, implies that the hunter shares some of the speaker's mood

In "Desert Places", the speaker is awed by the swift descent of snow and night. He is disheartened by the smooth white cover over the last traces of vegetation, which presents a temptation to yield, for everything seems gathered in. He participates as he yields the snowy field to the woods, envies the animals in their protective burrows, and feels so absent that he does not even count as part of the scene.

And lonely as it is that loneliness

Will be more lonely ere it will be less-

A blanker whiteness of benighted snow

With no expression, nothing to express. (Frost, 1995)

The speaker generalizes about the scene: its loneliness will intensify long before any relief arrives. The snow cover will thicken and be covered by night, and will lack physical expression and anything to say.

\section{B. Conveying "A Momentary Stay Against Confusion"}

Frost says in The Constant Symbol: Every poem is an epitome of the great predicament; a figure of the will braving alien entanglements. He means "figure" in its primary sense of "outline" or "form" (Frost, 1995, p.787). In Frost's poem, a figure is always a pattern of movement, a physical posture, or the man or animal performing the movement, assuming the posture. The poem does not stand for "the will braving alien entanglements"; it is "the imprint made on the world by this activity" (Wilcox, 1990, p.42). In The Figure a Poem Makes Frost declares: It runs a course of lucky events, and ends in a clarification of life — not necessarily a great clarification... but in a momentary stay against confusion (Frost, 1995, p.777). The movement, or the physical posture in Frost's poetry is a repeated gesture of defiance, each of which is "a momentary stay against confusion". The poems are full of such gesture of stay, transient but affirmative.

Frost presents man as a pilgrim seeking salvation and trying to demonstrate his moral worth in an imperfect world. Man's sacred acts become the physical acts through which he resists the gravitational pull of sleep, decay and death. In Frost's poems, often man is put in an environment in which nature objects produce various kinds of obstacles, difficulties and evil temptation.

The unknown woodsman in "The Wood-Pile" has left a human mark in that random wood where the view is "all in lines/Straight up and down of tall slim trees/Too much alike to mark or name a place by". The expense of his energy into that swamp has left the organized and ordered wood pile as the symbol of man's desire to make order out of the chaos of his environment. Having stacked his wood, he has turned on to fresh tasks, suggesting perhaps that the achievement of order is necessarily temporary.

All planting, building, tilling, chopping, line laying, all such acts are human acts of ordering chaos. One of the most famous of such acts in Frost's poetry is mending wall. It becomes increasingly clear that the wall mending is not being condemned by the speaker. The speaker criticizes his neighbor for not asking why they mend walls. He himself initiates the mending process itself. The wall is mended as a gesture against that "Something there is that doesn't love a wall,/ That wants it down". Together, the speaker and his neighbor are engaged in the fundamental human enterprise, making a momentary stand against the confusion that "spills the upper boulders in the sun".

In "Brown's Descent", the old farmer maintains his fight against the physical world, grimly and determinedly. Though he slides all the way down the mountain on the icy snow, he never gives up his struggle against gravity; and he wins too. For finally, bowing to natural laws, he goes around the mountain and re-establishes himself on top. He slips down two miles of mountainside, undaunted by the hour, the climb or the fact that he has to go miles out of his way to get back up.

"Stopping By Woods On a Snowy Evening" provides another example. Here the speaker struggles against and overcomes the temptation to yield to the seductive woods. He turns a resolute back on the loveliness of dark woods and cold snow, with a certain weariness and yet with quiet determination, to face the needs and demands of life.

"Come In" is another version of the same story. The speaker begins his poem by telling us that at twilight, at the edge of the woods, he hears a thrush singing. He is almost deluded into believing that the thrush is inviting him to join her in her lamentation. But in the concluding stanza, he says:

But no, I was out for stars:

I would not come in. (Frost, 1995)

His original plan was an evening walk to look at the stars, not to enter the darkened woods to listen to thrush music. He resists the invitation of the bird to go into the greater dark and lament. He resists, too, in the poem's final line, the temptation to read the world as inviting him to anything. He is out for stars, and he maintains his quest in the face of darkness and indifference.

"A Leaf Treader" describes an autumn day in New England. All day the speaker has tramped back and forth in his woodlot. The brightly colored autumn leaves are falling all about him, and he has trodden many a leaf into the mire underfoot. What has been worrying him comes out very clearly in the next stanza. The gist of the stanza is this: every autumn the speaker has 
come to speculate on whether he will end up on top of the autumn leaves or the autumn leaves will end up on top of him. The leaves have been threatening. The speaker acknowledges that he is deeply involved in the processes of nature and is momentarily tempted to respond. But he pulls himself together and with a remarkable shift in tone concludes the stanza and the poem:

But it was no reason I had to do because they had to go.

Now up my knee, to keep on top of another year of snow. (Frost, 1995)

By treading the falling leaves underfoot, the speaker maintains his integrity by remaining upright. With the last line, he remembers that his triumph over the autumn leaves may be short-lived. Man's effort never stops, soon the snowflakes will be coming down, and the next pressing problem will be to stay on top of the snow rather than to allow the snow to provide a winter blanket for them.

In the long poem "Snow", the preacher Meserve is making his way home through an evening blizzard. He stops at the Cole's more than mid way to his home. He can remain overnight with his neighbors with no inconvenience to them or himself. The snow outside is seen as a monstrous and stupid creature that Meserve seems to want to challenge and then as something that when banked high against a house creates a special pleasure for those protected inside. He says that he likes the snow from inside more than from outside but that he doesn't want to be considered less than birds who can survive in such a storm and thrive on the morrow, so it is evident that he must face the worst challenge of the outside in order to enjoy the inside. Repose for him must be earned rather than just accepted. Thus, after half an hour or so, he proceeds into the storm, comparing it to a war that one would feel compelled to join. He must go and conquer the blizzard.

In "Gathering Leaves", the speaker tries to bring to an end a season of decline by struggling endlessly to fill bags of autumn leaves.

Spades take up leaves

No better than spoons,

And bags full of leaves

Are light as balloons. (Frost, 1995)

The concise similes show the difficulty of the task. This task seems out of proportion to his progress. Gathered leaves make mountains, yet these are small. But the task is joyous as well as frustrating in its playful physical engagements, and the elusive leaves become an amusing burden. The task seems endless and the gathered leaves slight and valueless. It is less the achievement than the gesture of ordering that interests Frost. What is important is the courage and not the accomplishment.

\section{CONCLUSION}

Though Frost's poetry belongs to the Wordsworthian type which is plain, he lacks no creativity in his artistic technique. On the surface level, his poetry is simple and plain. Through the analysis of imagery in his poetry, a world of profound implication is manifested. The employment of imagery contributes a lot to the superficial simplicity of his poetry. But Frost hides behind a simple front, and he has proven more difficult of access in practical terms. He tries to put himself forward and remain in the background at the same time, and as a result produces poetry that is often quite deceptive for many readers. Without the study of the imagery in his poems, there is no comprehensive understanding of the poet.

\section{REFERENCES}

[1] Cai Zengliang. (1994). Fundamental Approaches to English Poetry. Shijiazhuang: He Bei Education Press.

[2] Cox, James M ed. (1962). Robert Frost. Englewood Cliffs: Prentice-Hall, Inc.

[3] Frost, Robert. (1995). Robert Frost. New York: Literary Classics of the United States.

[4] Gottesman, Ronald et al. eds (1979). The Norton Anthology of American Literature. New York: W. W. Norton and Company.

[5] Hall, Donald. (1977). Remembering Poets. New York: Harper \& Row, Publishers.

[6] Hart, James D ed (1995). The Oxford Companion To American Literature. Beijing: Foreign Language Teaching \& Research Press.

[7] Lathem, Edward Connery ed (1979). The Poetry of Robert Frost. N.Y: Henry Holy and Company.

[8] Lauter, Paul ed (1994). The Heath Anthology of American Literature. Lexington: D.C Heath and Company.

[9] Lewis, R. W. B and Warren, Robert Penn. (1973). American Literature. New York: St. Martin's Press, Inc.

[10] Lynen, John F. (1960). The Pastoral Art of Robert Frost. New Haven: Yale UP.

[11] Marcus, Mordecai. (1991). The Poems of Robert Frost. Boston: GK. Hall \& Co.

[12] Poirier, Richard. (1990). Robert Frost. Stanford: Stanford University Press.

[13] Potter, James L. (1982). Robert Frost Handbook. University Park and London: The Pennsylvania State University Press.

[14] Pritchard, William H. (1984). Frost. New York: Oxford University Press.

[15] Triha, Manorama ed. (1990). Robert Frost. Delhi: Ace Publications.

[16] Warren, Robert Penn and Lewis, R.W.B. (1973). American Literature. New York: St. Martin’s Press, Inc.

[17] Widdowson, H.G. (1992). Practical Stylistics. Shanghai: Shang Hai Foreign Language Education Press.

[18] Wilcox, Earl J ed. (1990). Robert Frost: The Man and The Poet. Conway: UCA Press.

[19] Wu Weiren ed. (1990). History and Anthology of American literature. Beijing: Foreign Language Teaching \& Research Press.

Qian Chen was born in Leling, China in 1974. She received her M.A. Degree in English language teaching from He Bei Normal University, China in 2002. 
She is currently an associate professor in English Department, De Zhou College, Dezhou, China. Her research interests include English language teaching and American literature.

Prof. Chen twice got the Prize awarded by De Zhou Social Science Association for her published articles. 